[解説]

\title{
川崎市における温室効果ガス削減貢献量評価の取組
}

望月 規弘 1 ,*, 大池 倫世 ${ }^{2}$, 西村 和彦 ${ }^{2}$, 石原 賢一 ${ }^{2}$

1 一般社団法人サステナブル経営推進機構, 2 川崎市

*連絡先: mochizuki@sumpo.or.jp

概要 : 本解説では、川崎市に扔ける温室効果ガス削減貢献量評価への取組「川崎メカニズム認証制度」について報 告する。この制度では、LCA 手法を活用して、市内事業者の優れた環境技術・製品・サービスを従来と比較して、 温室効果ガス削減貢献量を評価し、認証する。最大の特徽は、川崎市外にこれらの技術・製品・サービスが普及す ることによる域外貢献量の算定及び認証にある。川崎市では、本制度と「低 $\mathrm{CO}_{2}$ 川崎ブランド」の 2 つ制度に より、市内事業者の優れた環境技術を活かした取組を推進している。

キーワード：温室効果ガス、LCA、域外貢献量、川崎メカニズム認証制度、低 $\mathrm{CO}_{2}$ 川崎ブランド

\section{1. 取組背景と意義}

川崎市の臨海部は東京湾に面しており、石油コンビナー 卜や鉄鋼業、化学工業など大規模な工場が多く立地し、京 浜工業地帯の中核として日本の経済成長を牽引してきた。 その一方で、高度経济成長期には樑刻な公害問題に直面し たが、事業者・市民・行政の相互の連携により様々な公害 対策に取り組むことで改善を図ってきた。

この取組の過程で、市内には低炭素・公害対策・資源循 環・エネルギー等に関する多くの環境技術・環境産業が集 積している。

世界共通の課題である地球温暖化問題に対して、市内事 業者は、事業所から排出される温室効果ガスの削隇に取り 組むとともに、優れた環境技術を活かし、環境配慮製品・ 技術等の開発などを通じ、市域の枠を超えた製品の使用・ 消費時等の温室効果ガス排出量の削減に多大に貢献して いる。

川崎市では、このような市域の枠を超え温室効果ガス排 出量の削減に貢献している事業者が市場で適切に評価され る仕組みづくりを推進するため、LCA 手法を活用した「低 $\mathrm{CO}_{2}$ 川崎ブランド」「川崎メカニズム認証制度」を市独自 の制度として実施するとともに、広く発信している1)。こ れらの取組は、川崎の環境技術による市域外一の貢献と併 せて市内産業の振興を図ることを目的としている。

\section{2. 取組経過}

川崎市では、平成 21 年度から原料調達から廃裹・リサ イクルまでのライフサイクル全体を通じて、従来と比較し 温室効果ガスが削減された市内事業者の製品・技術等を
「低 $\mathrm{CO}_{2}$ 川崎ブランド」として認定する事業を実施しており、 令和 2 年度までに累計 105 件の製品・技術等が認定されて いる。

また、平成 25 年度からはライフサイクル全体を通じて、 市域外で温室効果ガス削減に貢献した量（以下「域外貢献 量」という。）を認証する「川崎メカニズム認証制度」を 実施しており、令和 2 年度までで累計 31 件の製品・技術等 に係る域外貢献量が認証されている。域外貢献量について は、平成 24 年度に「域外貢献量算定ガイドライン」を策 定し、その定義や算定方法を定めている ${ }^{2)}$ 。

これらの事業は川崎市が独自に推進していたが、認定・ 認証製品等の普及支援を一層強化するため、平成 28 年度 に「川崎市商工会議所」「(公財) 川崎市産業振興財団」、 $\lceil\mathrm{NPO}$ 法人産業・環境創造リエゾンセンター」「川崎信用 金庫」といった産業支援団体で構成する「低 $\mathrm{CO}_{2}$ 川崎ブラ ンド等推進協議会」を発足させ、川崎市による運営から協 議会による運営に移行した。

これにより、川崎市だけでなく、それぞれの団体の情報 発信手法や企業支援策を用いて、個々の認定・認証企業が 必要としている支援に幅広く対応することが可能となった。

「低 $\mathrm{CO}_{2}$ 川崎ブランド」「川崎メカニズム認証制度」の 取組経過は以下のように要約される。

・平成 21 年〜低 $\mathrm{CO}_{2}$ 川崎ブランド事業実施（現在まで 継続実施)

・平成 23 年 1 月〜 LCA 手法を活用した「域外貢献量」 の算定手法と「量」の認証制度について、学識者を 含めた検討

・平成 24 年 5 月「域外貢献量算定ガイドライン」の策定 
・平成 25 年 4 月「川崎メカニズム認証制度」の開始

・平成 28 年 4 月「低 $\mathrm{CO}_{2}$ 川崎ブランド等推進協議会」 の発足（事業の運営）

・平成 29 年 12 月 本事業の取組が評価され、低 $\mathrm{CO}_{2}$ 川 崎ブランド等推進協議会が「地球温暖化防止活動環 境大臣表彰」を受賞

\section{3. 域外貢献量の算定}

\section{1 はじめに}

「川崎メカニズム認証制度」においては、平成 24 年度に 「域外貢献量算定ガイドライン」を策定し、域外貢献量の 定義や算定方法を定めている。以下、本ガイドラインにつ いて紹介する。

\section{2 域外貢献の定義}

域外貢献とは、川崎市内の事業者等における優れた製 品・技術・研究開発などによる温室効果ガスの削減のうち、 次のいずれにも該当するものを「域外貢献」として定義し ている。

(1)原料調達から廃累・リサイクルまでのライフサイクル 全体を考虑し、従来の製品・技術等と比較して削減に 寄与するもの

(2)市域外の削減に貢献するもの

\section{3 域外貢献活動の類型化}

市内における事業活動等によって市域外での温室効果ガ ス削減に貢献する取組を次の 5 つに分類している。いずれ も川崎市域外での温室効果ガスの削減に貢献するものが対 象となる。

a 研究開発：川崎市内で研究開発された技術により貢 献

b ものづくり（素材・部材）：川崎市内で製造された 素材・部材が川崎市内外で最終製品化され貢献

c ものづくり（最終製品）：川崎市内で最終製品化され 貢献

d エネルギー供給：川崎市内で発生させたエネルギー が川崎市外に供給され貢献

e その他：上記に属さないもの

\section{4 域外貢献量の算定方法の概要}

域外貢献量の算定にあたっては、次の 3 項目について把 握する。

(1)ライフサイクル評価に基づく川崎市域外での正味の削 減量

(2)削減寄与率

(3)川崎市域外への普及量
ある製品・技術等による域外貢献量はこれらの 3 項を乗 じて算定する。

図 1 に域外貢献量の算定フローを示す。

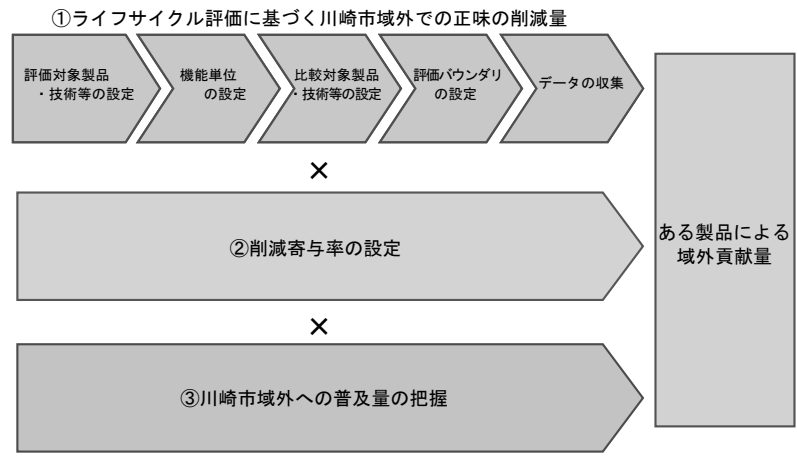

図1域外貢献量の算定フロー

\section{5 域外貢献量の算定方法}

\subsection{1 製品 1 単位あたりのライフサイクル評価}

製品 1 単位あたりのライフサイクル評価は、次の 5 ス テップが挙げられる。

(1)評価対象製品・技術等の設定

(2)機能単位の設定

(3)比較対象製品・技術等の設定

(4)評価バウンダリの設定

(5)データの収集、算定

\subsubsection{1 評価対象製品・技術等の設定}

ライフサイクル評価を行う際には、まず評価の対象とす る製品・技術等を定義する。評価対象は、ライフサイクル のいずれかの段階において川崎市域外での温室効果ガスの 削減に貢献する製品・技術等である。

\subsubsection{2 機能単位の設定}

機能単位とは各製品・技術がどのような機能を有してい るかについて定義し、その機能をある単位で定量化したも のである。前述のように、ある製品・技術等による域外貢 献量は、製品・技術 1 単位あたりの削減量に寄与率と普及 量を乗じて算出する值であるため、ここでは「製品・技術 1 単位」が機能単位の前提となる。そのため、例えばある 製品のライフサイクルにおける生産段階の温室効果ガス排 出量を算定するためには「製品 1 単位を製造すること」が 機能単位となり、使用段階を算定するためには「○○の能 力を持つ（○○の効果を得られる）製品 1 単位を $\bigcirc$ 時間使 用すること」が機能単位となる。

\subsubsection{3 比較対象製品・技術等の設定}

評価対象とする製品・技術等が、ライフサイクルにおい 
て川崎市域外の温室効果ガス排出削減に寄与していること を示すために、当該評価対象製品・技術等が存在しなかっ た場合と比較を行うこととなる。ここで、ライフサイクル 評価全体の信頼性という観点から、次のポイントに留意し て適切に比較対象製品・技術等の特定を行うこととして いる。

・消費者（利用者）が同じ機能を得ることが出来る（= 機能単位が同一である）一般的な製品・技術等を比 較対象に設定する。

・評価対象が新たな製品・技術等の場合、当該製品・技 術等がなかった場合を仮定した上で、比較対象を特 定する。

・研究開発及びものづくりに関しては、比較対象となる 製品は極力現存する製品の中での平均的な効率を採 用する。

・比較対象として想定する製品・技術等が極端に古い場 合は、比較対象として採用した根拠をより明確に提 示する。

・エネルギー供給の場合、すなわち、川崎市内で生成さ れたエネルギーの川崎市域外への供給が域外貢献活 動に該当する場合には、比較対象となるエネルギーは、 評価対象エネルギーが供給されなかった場合に供給 されたであろうエネルギーとなる。例えばメガソー ラー発電により電力の使用による排出量を削減する 場合には、系統電力が比較対象エネルギーとなる。

・ある時点にライフサイクルでの削減効果があると判断 されても、一定の年数を経た場合、削減効果は小さ くなるか、消滅すると考えられるため、定期的に比 較対象を見直す。

\subsubsection{4 評価バウンダリの設定}

図 2 に評価バウンダリ設定の基本的な考え方を示す。 域外貢献量の評価においては、評価対象と比較対象で、 評価バウンダリを整合させる。基本的には、原材料調達、 生産、流通・販売、使用・維持管理、廃棄というライフサ イクルの各段階を算定対象とするが、川崎市内における排 出の増減は評価の対象外となることから、評価バウンダリ 設定において市内の排出と市外の排出を整理した上で、市 外の排出のみを算定対象範囲とする。ただし、市外の排出 段階であっても、評価対象と比較対象で排出量が変わらな い場合は、評価バウンダリに含めなくて良いとしている。

製品が自社より下流側でリサイクルされた場合は、リサ イクルされた後の最終廃棄までを評価バウンダリとして、 その際は、機能単位の設定（使用年数設定など）を適切に 行う。

また、エネルギー供給の場合、生成したエネルギーを販
売製品とみなし、エネルギー生成時の排出のみを評価バウ ンダリとし、エネルギー供給設備自体の設置や廃鲜などに 伴う排出は算定対象外としている。

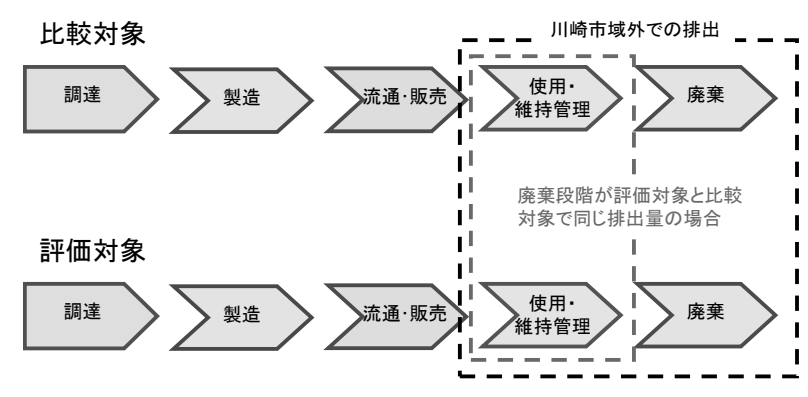

図2 評価バウンダリ設定の基本的な考え方

\subsubsection{5 データの収集}

一次デー夕については、実測による他、原材料購入量 (金 額）やエネルギー消費量の帳票などに基づいて把握するこ とができるデー夕、または対象製品・技術等のライフサイ クルプロセスに関連するサプライヤーから入手するデー夕 としている。一方、二次データについては国立研究開発法 人産業技術総合研究所が開発したインベントリデータベー ス IDEAv2.3を第 1 優先とし、そのほか、経済産業省なら びにNEDO技術開発機構の推進の「LCAプロジェクト」 の成果であるLCA 日本フォーラムのデータや国立環境研 究所が開発した産業連関表による環境負荷原単位デー夕 ブック 3EIDなども使用することができる。

\subsection{2川崎市内の事業者による貢献度（削減寄与率）}

削減寄与率とは、対象製品・技術のみが改良され、最終 製品を構成する他の製品・技術等において改良が行われな かったと仮定した場合の排出削減量の実際の排出削減量 （他の製品・技術を含めた全体の削滅量）に対する比率と 定義している。

この削減寄与率は、エネルギー供給以外の取組について 適用を検討することとし、エネルギー供給の場合、川崎市 内で生成されたエネルギーそのものを最終製品とみなし、 全量川崎市内の貢献分とみなす。

削減寄与率の寄与度の分解を厳密に行うことは困難なた め、寄与する段階（例えば研究開発のみ）の削減効果の全 量を域外貢献量として計上する（寄与率を $100 \%$ とする） ことも考えられるが、川崎市内の事業活動による域外貢献 量の算定は、川崎市内に立地する事業所の活動等に伴う温 室効果ガス排出量に対応させるべきであることから、寄与 度分解を行うことを基本的な方針とし、適切な寄与率の設 定を行うものとする。

最終的に製品となる場合の寄与率を考える際は、研究開 
発の寄与、素材・部材製造の寄与、最終製品製造の寄与、 という 3 段階での寄与があるという前提のもとで、川崎市 内の事業所の寄与率を設定する。ただし、川崎市内の事業 者が一体となって研究開発から製造まで行っている場合の 寄与率は $100 \%$ とする。

研究開発分については、自社内で研究開発から最終製品 製造までを一貫して行っている場合などで、自社内で適切 な比率が設定可能な場合は、その比率を適用する。

自社内での把握が難しく適切な寄与率が設定できない場 合は、川崎市産業連関表の基本取引表（108 部門）におけ る列方向の「研究」と「内生部門計」の比率を、研究開発 による寄与率とする。

素材加工と製品加工の寄与度分解については、域外貢献 に寄与する素材を用いていない最終製品の排出量が実測で きる場合、排出量の変化を実測することで素材加工と製品 加工の寄与分を把握する。排出量の実測が難しい場合には、 技術情報などを活用して寄与分を把握する。

上記のいずれの手法も適用が難しい場合は、最終製品に 着目した上で、我が国全体の産業連関表の中間投入から域 外貢献に資する業種を特定し、当該業種の中間投入額で素 材加工と製品加工の比率を設定し、寄与度として用いる。 図3に削減寄与率の考え方を示す。

なお、出荷時点のものが最終製品ではなく中間製品で あっても、出荷時点の状態で削減に寄与するものであって、 ライフサイクル評価が出荷時点の中間製品に対してなされ ているものであれば、出荷時点の中間製品を生産する工程 を製品加工に該当するものと整理する。

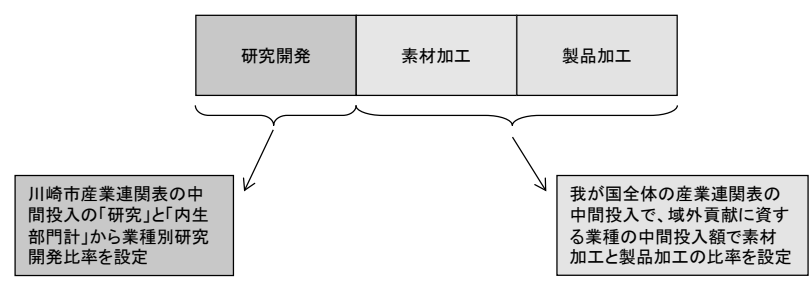

図3 削減寄与率の考え方

\subsection{3 当該製品の川崎市域外への普及量}

3.5 .1 では製品 1 単位あたりのライフサイクルでの温室効 果ガス削減量を算出する方法を示したが、製品製造者の域 外貢献量は、当該製品の川崎市域外への普及量を乗じて算 定する。その際、次の点に留意する。

・普及量計上の時期としては販売 (出荷) 時点でカウン トする。

・普及量の時間的範囲としては単年度の普及量を把握す る。

・川崎市内での普及量を把握し控除する

\subsubsection{1 普及量計上時期}

普及量計上の時期については、正確な域外貢献量の算定 という観点からは、削減効果が顕在化する時点（製品が使 用される時点）の量を把握することが望ましい。

しかし、販売された製品が必ずしもその年に使用される とは限らないなどの理由から、削減効果が顕在化する時点 での普及量を製品の製造者が正確に把握することは困難で あるため、販売量または出荷量を普及量とみなす。なお、 販売量と出荷量では販売量の方が削減効果が顕在化する時 点により近いと考えられるため、販売量を優先的に利用し、 販売量の把握が難しい場合に出荷量を把握する。

そして、本制度では、3.5.1.2 の製品 1 単位におけるライ フサイクル排出量の機能単位と連動するものとして、図 4 に示すように製品の使用年数分の削減効果を計上する。

なお、エネルギー供給の場合、対象となるエネルギー供 給設備が 1 年間に発生させるエネルギー量を普及量として 扱う。

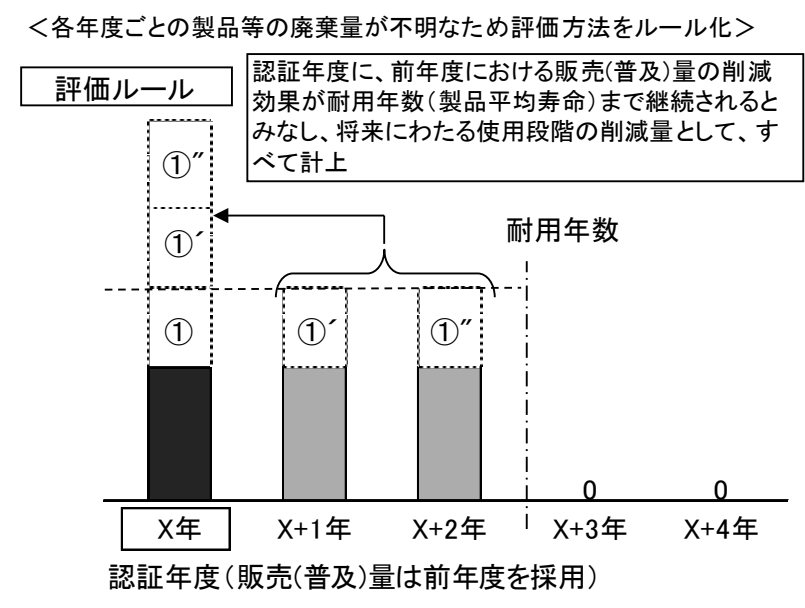

図4 削減効果の計上方法

\subsubsection{2 控除すべき川崎市内普及量の把握}

域外貢献量の算定に利用する普及量は、3.5.3.1 で把握す る販売量、出荷量から川崎市内への普及量を控除する。こ こで、正確な川崎市内での販売量（川崎市内への出荷量） が不明な場合は、適切な按分指標を設定した上で普及量を 算出するものとする（例えば、家電製品であれば全国と川 崎市の世帯数によって按分するなど)。ただし、このよう な按分を行う際には、当該製品の特性を勘案して極力地域 性を考慮して按分すること（例えば都道府県別の販売台数 を考慮するなど)。

なお、算定対象が製品ではなく川崎市内でつくられた再 生可能エネルギーである場合、控除すべき量は川崎市内で 消費された再生可能エネルギーとなる。 


\section{4. 審査・認証}

前章に従って算定された市内事業者の製品・技術等の域 外貢献量について、次の事項の妥当性等を審査した上で、 数值を認証する。

（1）域外貢献の基本的な要素

（ア）域外貢献活動の類型の設定

（イ）ライフサイクル全体での温室効果ガス排出量の削 減

（ウ）追加性・独自性・先進性

ここで、追加性とは、国外も含め川崎市域外において 従来製品と比較して追加的にライフサイクルでの GHG 排出量を削減すること、独自性とは、事業者独 自の技術を活かしていること、先進性とは他の類似製 品・技術と比較して、先進的な排出削減効果を有して いることである。

（2）具体的な域外貢献量の算定方法

（ア）ライフサイクル評価に基づく川崎市域外での正味 の削隇量設定方法

評価対象製品・技術等の設定方法／機能単位の設定方 法 / 比較対象製品・技術等の設定方法／評価バウンダ リの設定方法／データの収集方法など

（イ）川崎市内の事業者による貢献度（削減寄与率）の 設定方法

削減寄与率の設定方法／データの把握方法など

（ウ）川崎市域外への普及量の把握方法

普及量計上時期及び普及量の範囲／普及量の把握・設 定方法など

\section{5. 域外貢献量の実績}

「川崎メカニズム認証制度」において、2.でも述べたと おり平成 25 年度から令和 2 年度まで累計 31 件の製品等に 係る域外貢献量が認証された。川崎市では、これら認証数 值と、認証製品・技術等の年度ごとの普及量実績から、年 度ごとに域外貢献量を推計している。域外貢献量の実績を 表5にまとめる。

ここで、当該年度の域外貢献量は、製品等が耐用年数に わたり継続して普及しているとして計上している。すなわ ち、ある年度の普及量による域外貢献量を耐用年数で割っ た值を単年度域外貢献量と定義し、耐用年数内の単年度域 外貢献量の合算値を当該年度の域外貢献量としている。

表 5 域外貢献量の実績

\begin{tabular}{|c|c|c|c|c|c|}
\hline 年度 & $\begin{array}{c}\text { 平成 } 26 \\
(2014)\end{array}$ & $\begin{array}{c}\text { 平成 } 27 \\
(2015)\end{array}$ & $\begin{array}{c}\text { 平成 } 28 \\
(2016)\end{array}$ & $\begin{array}{l}\text { 平成 } 29 \\
(2017)\end{array}$ & $\begin{array}{l}\text { 平成 } 30 \\
(2018)\end{array}$ \\
\hline $\begin{array}{c}\text { 域外貢献量 } \\
\left(\mathrm{CO}_{2} \text { 換算 }\right)\end{array}$ & 285 万トン & 329 万トン & 314 万トン & 307 万トン & 475 万トン \\
\hline
\end{tabular}

\section{6. おわりに}

川崎市では、「低 $\mathrm{CO}_{2}$ 川崎ブランド」、「川崎メカニズム 認証制度」の取組により、市域の朹を超えた温室効果ガス の削減に貢献する環境に配慮した製品・技術等の開発と浸 透を促進している。

2050 年の脱炭素社会の実現に向け、これらの取組を更 に推進し、川崎発のグリーンイノベーションの促進や市内 事業者の国際競争力の向上につなげていく。

(2021年2月 8 日受付)

\section{参照文献}

1) 低 $\mathrm{CO}_{2}$ 川崎市ブランド等推進協機会 (n.d.), 低 $\mathrm{CO}_{2}$ 川崎 ブランド・川崎メカニズム認証制度ホームページ, 入 手先 <http://www.k-co2brand.com/>，参照日 202103-01)

2) 川崎市 (2013), 川崎市域外貢献量算定ガイドライン, 低 $\mathrm{CO}_{2}$ 川崎ブランド・川崎メカニズム認証制度ホーム ページ, 入手先 <http://www.k-co2brand.com/ mechanism/src/pdf/guidline.pdf>, （参照日 2021-0301) 


\title{
[Commentary and Discussion]
}

\section{Activities of GHG Avoided Emission Evaluations in Kawasaki City}

\author{
Norihiro MOCHIZUKI ${ }^{1, *}$, Michiyo OIKE ${ }^{2}$, Kazuhiko NISHIMURA ${ }^{2}$ and Kenichi ISHIHARA ${ }^{2}$ \\ 1 Sustainable Management Promotion Organization; 2 Kawasaki City \\ *Corresponding author: mochizuki@sumpo.or.jp
}

Synopsis: We report on the "Kawasaki Mechanism Certification System", an initiative to evaluate avoided greenhouse gas emissions in Kawasaki City. This system assesses and certificates the avoided Greenhouse Gases (GHGs) emissions of the excellent environmental technologies, products, and services in Kawasaki City by comparing with conventional technologies on the basis of the LCA method. The key feature of this system is the assessment and certification of the contribution to GHG emission reductions outside the city. Kawasaki City is promoting activities to utilize the excellent environmental technologies of enterprises within the City through this system and the "Low $\mathrm{CO}_{2}$ Kawasaki Brand" system.

Keywords: greenhouse gas; life cycle assessment; contribution to GHG emission reductions outside the city (avoided emissions); Kawasaki Mechanism Certification System; Low $\mathrm{CO}_{2}$ Kawasaki Brand 